\title{
Seismic investigations of the Martian near-surface ata the InSight landing site
}

\section{Other Conference Item}

\section{Author(s):}

Schmelzbach, Cédric (D); Brinkman, Nienke; Sollberger, David (D); Andersson, Fredrik; Robertsson, Johan O.A.; van Driel, Martin; Stähler, Simon Christian (D); ten Pierick, Jan; Giardini, Domenico; InSight SEIS; Near Surface Team; et al.

\section{Publication date:}

2020-05-04

Permanent link:

https://doi.org/10.3929/ethz-b-000461900

\section{Rights / license:}

Creative Commons Attribution 4.0 International

Originally published in:

EGUsphere, https://doi.org/10.5194/egusphere-egu2020-20481 


\section{EGU2020-20481}

https://doi.org/10.5194/egusphere-egu2020-20481

EGU General Assembly 2020

(c) Author(s) 2021. This work is distributed under

the Creative Commons Attribution 4.0 License.

\section{Seismic investigations of the Martian near-surface at the InSight landing site}

Cedric Schmelzbach ${ }^{1}$, Nienke Brinkman ${ }^{1}$, David Sollberger ${ }^{1}$, Sharon Kedar ${ }^{2}$, Matthias Grott ${ }^{3}$, Fredrik Andersson ${ }^{1}$, Johan Robertsson ${ }^{1}$, Martin van Driel ${ }^{1}$, Simon Stähler ${ }^{1}$, Jan ten Pierick ${ }^{1}$, Troy Hudson ${ }^{2}$, Kenneth Hurst ${ }^{2}$, Mellanie Drilleau ${ }^{4}$, Balthasar Kenda ${ }^{4}$, Raphael Garcia ${ }^{5}$, Naomi Murdoch ${ }^{5}$, Domenico Giardini ${ }^{1}$, Philippe Lognonne ${ }^{4}$, W. Tom Pike ${ }^{6}$, Tilman Spohn ${ }^{3}$, and the InSight SEIS and Near Surface Team ${ }^{*}$

${ }^{1}$ ETH Zurich, Institute of Geophysics, D-ERDW, Zurich, Switzerland (cedric.schmelzbach@erdw.ethz.ch)

${ }^{2}$ Jet Propulsion Laboratory, California Institute of Technology, USA

${ }^{3}$ Deutsches Zentrum für Luft und Raumfahrt, Germany

${ }^{4}$ Institut de Physique du Globe de Paris, France

${ }^{5}$ Institut Supérieur de l'Aéronautique et de I'Espace (ISAE), France

${ }^{6}$ Imperial College, London, UK

${ }^{*}$ A full list of authors appears at the end of the abstract

The InSight ultra-sensitive broadband seismometer package (SEIS) was installed on the Martian surface with the goal to study the seismicity on Mars and the deep interior of the Planet. A second surface-based instrument, the heat flow and physical properties package $\mathrm{HP}^{3}$, was placed on the Martian ground about $1.1 \mathrm{~m}$ away from SEIS. HP $\mathrm{H}^{3}$ includes a self-hammering probe called the 'mole' to measure the heat coming from Mars' interior at shallow depth to reveal the planet's thermal history. While SEIS was designed to study the deep structure of Mars, seismic signals such as the hammering 'noise' as well as ambient and other instrument-generated vibrations allow us to investigate the shallow subsurface. The resultant near-surface elastic property models provide additional information to interpret the SEIS data and allow extracting unique geotechnical information on the Martian regolith.

The seismic signals recorded during $\mathrm{HP}^{3}$ mole operations provide information about the mole attitude and health as well as shed light on the near-surface, despite the fact that the $\mathrm{HP}^{3}$ mole continues to have difficulty penetrating below $40 \mathrm{~cm}$ (one mole length). The seismic investigation of the $\mathrm{HP}^{3}$ hammering signals, however, was not originally planned during mission design and hence faced several technical challenges. For example, the anti-aliasing filters of the seismic-data acquisition chain were adapted when recording the mole hammering to allow recovering information above the nominal Nyquist frequency. In addition, the independently operating SEIS, $\mathrm{HP}^{3}$ and lander clocks had to be correlated more frequently than in normal operation to enable high-precision timing.

To date, the analysis of the hammering signals allowed us to constrain the bulk P-wave velocity of the volume between the mole tip and SEIS (top $30 \mathrm{~cm}$ ) to around $120 \mathrm{~m} / \mathrm{s}$. This low velocity value is 
compatible with laboratory tests performed on Martian regolith analogs with a density of around $1500 \mathrm{~kg} / \mathrm{m}^{3}$. Furthermore, the SEIS leveling system resonances, seismic recordings of atmospheric pressure signals, $\mathrm{HP}^{3}$ housekeeping data, and imagery provide additional constraints to establish a first seismic model of the shallow (topmost meters) subsurface at the landing site.

InSight SEIS and Near Surface Team: Cedric Schmelzbach, Nienke Brinkman, David Sollberger, Sharon Kedar, Matthias Grott, Fredrik Andersson, Johan Robertsson, Martin van Driel, Simon Stähler, Jan ten Pierick, Troy L. Hudson, Kenneth Hurst, Melanie Drilleau, Balthasar Kenda, Raphael Garcia, Naomi Murdoch, Domenico Giardini, Philippe Lognonné, W. Tom Pike, Tilman Spohn, W. Bruce Banerdt, Lucile Fayon, Anna Horleston, Aaron Kiely, Brigitte Knapmeyer-Endrun, Christian Krause, Nicholas C. Schmerr, Pierre Delage, Nick Teanby, Christos Vrettos 